\begin{tabular}{|c|c|}
\hline (12) & Pago $t$ of 1 \\
\hline JUN 051996 & 1. EDr 609910 \\
\hline
\end{tabular}

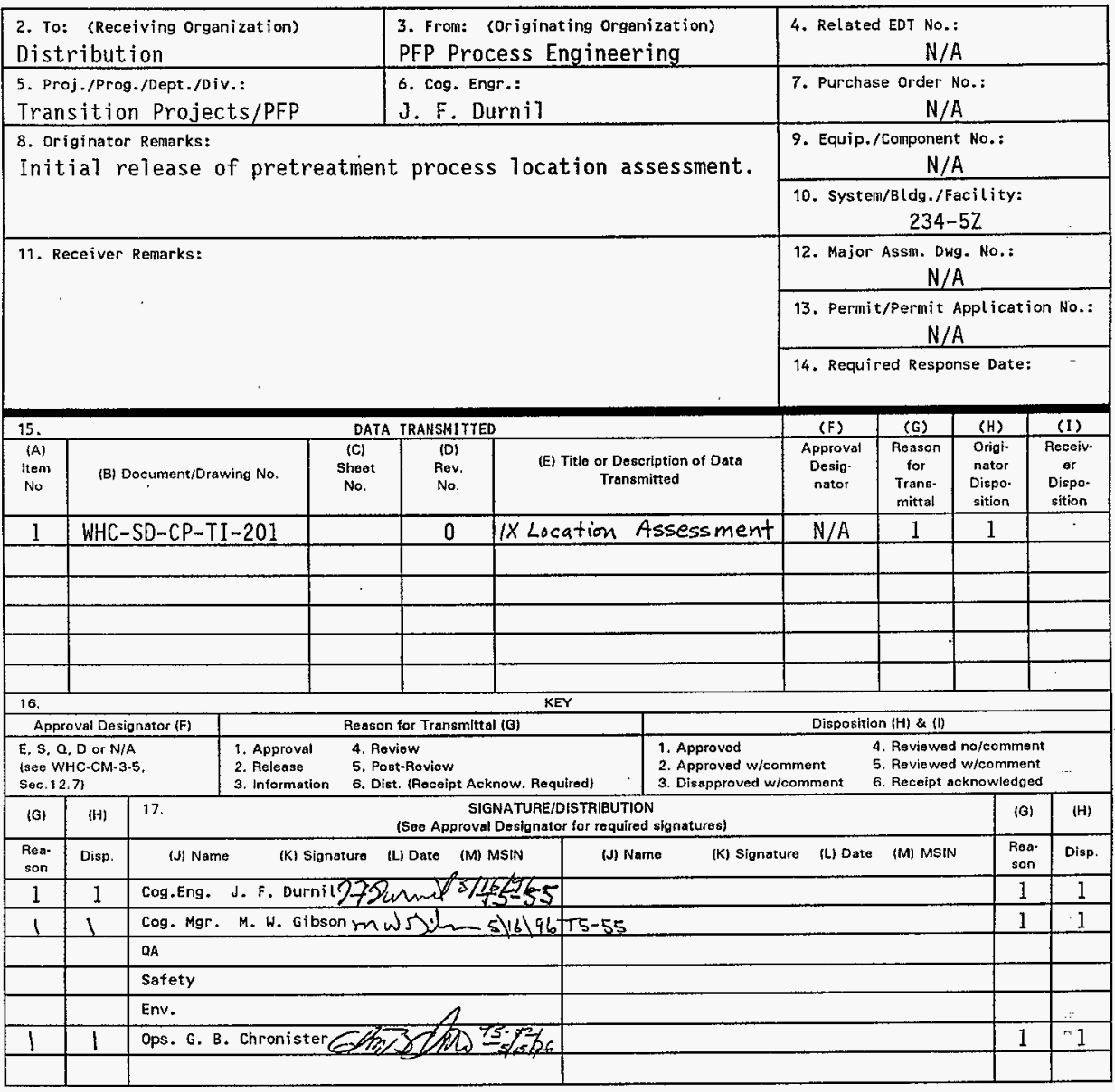

\begin{tabular}{|c|c|c|c|}
\hline CPMnery $5 / 16 / 96$. & 19. & 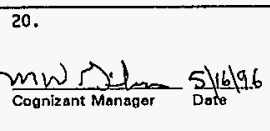 & $\begin{array}{l}\text { 21. DOE APPROVAL (if required) } \\
\text { Ctrl. No. } \\
\text { [2 Approved } \\
\text { [] Approved w/comments } \\
\text { [1] Disapproved w/comments }\end{array}$ \\
\hline
\end{tabular}

BD-7400-172-2 (04/94) GEF097 
HHC-SD-CP-TI-201, Rev. 0

\title{
LOCATION ASSESSMENT FOR THE LIQUID PRETREATMENT PROCESS
}

\author{
J. F. DURNIL and C. D. MENG
}

Westinghouse Hanford Company, Richland, WA 99352

U.S. Department of Energy Contract DE-AC06-87RL10930

$\begin{array}{lll}\text { EDT/ECN: } & 609910 & \text { UC: UC-721 } \\ \text { Org Code: } & 15530 & \text { Charge Code: } \\ \text { B\&R Code: } & \text { EW7003000 } & \text { Total Pages: } 28\end{array}$

Key Words: PRETREATMENT, ION EXCHANGE, DENITRATION, 94-1

Abstract: Some of the Pu bearing solutions at PFP have chemical species that are not compatible with the vertical calcination process. These elements ( $\mathrm{Na}, \mathrm{K}$, etc.) need to be removed prior to processing in the calciner. The proposed means of removing the contaminates are ion exchange and EIChrom resin (EIChrom is a trademark of EIChrom Industries, Inc.). This limited assessment study evaluated possible locations for the liquid pretreatment process and selected glovebox HC$7 \mathrm{C}$ as the best location for this process in the PFP.

TRADEMARK DISCLAIMER. Reference herein to any specific comercial product, process, or service by trade name, trademark, manufacturer, or otherwise, does not necessarily constitute or imply its endorsement, recomendation, or favoring by the United states Government or any agency thereof or its contractors or subcontractors.

Printed in the United States of America. To obtain copies of this document, contact: WHC/BCS Document Control Services, P.O. Box 1970, Mailstop H6-08, Richland WA 99352, Phone (509) 372-2420; Fax $(509) 376-4989$.

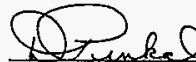
Release Approval

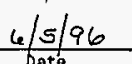
bate

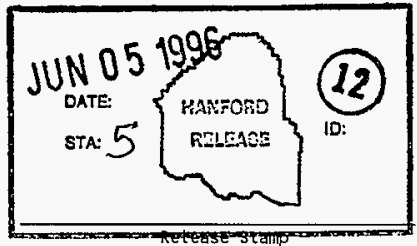


WHC-SD-CP-TI-201

REV. 0

\section{LOCATION ASSESSMENT FOR THE LIQUID}

PRETREATMENT PROCESS

AUTHOR: J. F. DURNIL and C. D. MENG

PFP PROCESS ENGINEERING

PFP ENGINEERING 


\section{TABLE OF CONTENTS}

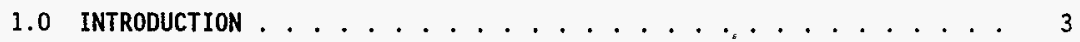

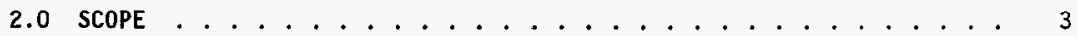

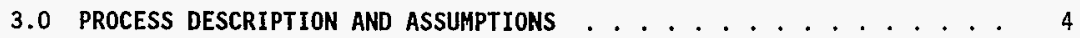

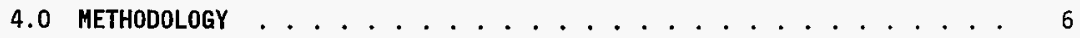

5.0 EVALUATION OF GLOVEBOXES .................. 6

5.1 G1oveboxes Eliminated. . . . . . . . . . . . . 6

5.2 Gloveboxes Considered . . . . . . . . . . 7

5.3 Description of the Gloveboxes . . . . . . . 7

5.4 Evaluation Against Criteria . . . . . . . . . . 8

5.5 Additional Information ................ 15

6.0 advantages AND Disadvantages . . . . . . . . . . . . 17

7.0 CONCLUSIONS AND RECOMMENDATIONS . . . . . . . . . . . . . 19

APPENDIX A ALARA CONSIDERATIONS ................ 23

LIST OF FIGURES

FIGURE 1. PRETREATMENT PROCESS SCHEMATIC . . . . . . . . . . 20

FIGURE 2. PRETREATMENT IN THE HC-7C GLOVEBOX . . . . . . . . . 21

FiguRE 3. PRETREATMENT IN THE HA-46 GLOVEBOX . . . . . . . . . . . . . 22

FIGURE A. 1 DOSE MAP OF HC-7C, ROOM 228B, AND ROOM 232 AREAS. . . . . 27 LIST OF TABLES

TABLE 1. EVALUATION OF GLOVEBOXES CONSIDERED FOR INSTALLATION OF THE

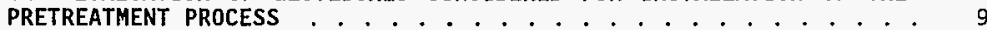

TABLE 2. EVALUATION OF NEW GLOVEBOXES CONSIDERED FOR INSTALLATION OF THE PRETREATMENT PROCESS 


\subsection{INTRODUCTION}

Some of the plutonium bearing solutions at the Plutonium Finishing Plant (PFP) have chemical constituents that are not compatible with the vertical calcination process. These elements ( $\mathrm{Na}, \mathrm{K}$, etc.) need to be removed prior to processing the Pu-bearing solutions in the vertical denitration calciner. The proposed means of removing the contaminants are ion exchange (IX) and EIChrom resin (EIChrom is a trademark of EIChrom Industries, Inc.).

The purpose of this 1 imited assessment is to study possible locations for the IX or EIChrom process at the PFP and establish the location.

\subsection{SCOPE}

The 94-1 solutions to be processed in the vertical calciner include the following:

1) Product Plutonium nitrate solution from the Plutonium Uranium Extraction Facility (PUREX) and Plutonium Reclamation Facility (PRF) processes. This solution is contained in Product Receiver (PR) cans (100 items with approximately $250 \mathrm{~kg}$ total $\mathrm{Pu}$ ) and needs no pretreatment. (The total nominal volume of these $100 \mathrm{PR}$ cans before flush is $850 \mathrm{~L}$.)

2) Concentrated filtrate solution contained in PR cans (180 items with approximately $40 \mathrm{~kg}$ total $\mathrm{Pu}$ ). Laboratory testing has indicated that these solutions will need pretreatment by ion exchange or EIChrom to remove the potassium (which could affect the quality of the calcine produced) prior to sending the solution to the calciner. (The total nominal volume of these 180 $P R$ cans before flush is 1530 L.)

3) Flush solutions contained in PR cans and L-10 type containers (151 items with about $50 \mathrm{~kg}$ total $\mathrm{Pu}$ ). Laboratory testing has also indicated that these solutions will probably need pretreatment due to uncertain composition. These solutions have unacceptably high levels of sodium which would be removed by the pretreatment process before being sent to the calciner. The pretreatment system will probably be designed and operated to route uranium in those flush items containing uranium to the plutonium rich eluant stream. (The total nominal volume of these 151 .containers before flush is $1432 \mathrm{~L}$.)

4) Other nitric acid flush solutions generated during Terminal clean out activities (volume unknown).

The scope of this document is to evaluate the existing gloveboxes in the various standby systems at the PFP and a new glovebox for housing the pretreatment process. Criteria for evaluation includes glovebox size, ALARA, security, and criticality requirements. Logistics for interaction with other 94-1 operations has at so been considered. 


\subsection{PROCESS DESCRIPTION AND ASSUMPTIONS}

The IX or EIChrom process consists of a Feed Receiving and Adjustment Tank, a Feed Pump Tank, the IX or EIChrom column, an Eluate Receiving and Adjustment Tank, and Feed/Wash Raffinate collection tanks. See Figure 1 for a schematic. The process solutions will be vacuum transferred from PR cans in the HC-227S/T glovebox into two $40 \mathrm{~L}$ tanks located in glovebox $\mathrm{HC}-227 \mathrm{~S}$. The solution is then pumped to the Feed Receiving and Adjustment Tank where the acidity may be adjusted as needed. The solution flows by gravity to the Feed Pump Tank for sampling or any other preparation. Following the Feed Pump Tank the solution is pumped to the IX or EIChrom column where the Pu is collected on the chosen resin. The solution leaving the column is sampled and sent to the 241-z facility as waste. Following operation at three column volumes per hour, the loaded column is eluted with dilute nitric or formic acid. The eluate is collected in a tank, sampled, $\mathrm{pH}$ adjusted as necessary, and sent to storage in $\mathrm{HC}-227 \mathrm{~S}$ prior to being introduced to the vertical denitrator calciner as feed.

The following processing assumptions were made:

1) Feed material processed with IX or EIChrom will include all Pu-bearing solutions in the inventory except PRF/PUREX nitrate.

2) $\mathrm{Pu}$ content is based on an estimate of 85 percent weapons grade, and 15 percent fuels grade and americium ingrowth as estimated by crowe and Szempruch (1994).

3) All nitrate solutions are filtered in $\mathrm{HC}-227 \mathrm{~S}$ before processing. Solid $\mathrm{AnO}_{2}$ is removed in this step.

4) Based on the extended time interval since the solutions were processed, all plutonium will be in the +4 valence. Therefore, valence adjustment of the feed is not required.

5) Americium and other metall ic impurities do not absorb well on the resin. Most of the metallic impurities carry through the column with the waste in the loading step, with some limited removal by the short wash step.

6) Typical column operation is to load to 60-80 percent ( $P u+U$ ) capacity, with feed (about $7.4 \mathrm{M} \mathrm{HNO}_{3}$ ) at about $12-20 \mathrm{~L} / \mathrm{hr}$, wash (about $7 \mathrm{M} \mathrm{HNO}_{3}$ ) with about $12 \mathrm{~L}$ at $12-20 \mathrm{~L} / \mathrm{hr}$, elute (about $0.35 \mathrm{M} \mathrm{HNO}_{3}$ ) with about 20 liters at $12 \mathrm{~L} / \mathrm{hr}$. Column regeneration between cycles will probably not be necessary for anion exchange, but would probably be necessary for EIChrom resin, estimated at $20 \mathrm{~L}$ at $30 \mathrm{~L} / \mathrm{hr}$.

7) All ions but $\mathrm{Pu}$ and $\mathrm{U}$ flow through the column to the raffinate in either the loading or wash step.

8) Liquid waste is neutralized in 241-Z with approximately 11 molar $\mathrm{KOH}$ before being transferred to tank farm waste tanks. 
9) Volume increase due to neutralization is approximately 30 percent after neutralization with $11 \mathrm{molar} \mathrm{KOH}$.

10) The initial resin charge is expected to last the entire processing campaign. The waste volume is resin only; 50 volume percent increase is assumed for disposal.

11) $\mathrm{Pu}$ concentration 1 imit in liquid waste (raffinate plus $\mathrm{NaOH}$ addition) is $0.013 \mathrm{~g} / \mathrm{L}$ and waste concentration can be met by complete elution of the column and rework of loading/wash raffinate through the eluted column.

The IX column or EIChrom column is approximately 4 feet tall with additional clearances for maintenance and has a diameter of 6 inches. The remaining tanks will be 6 inches in diameter which include the feed receipt and adjustment tank, the feed pump tank, the waste collection tank, and the product material tank. The criticality spacing between equipment is given below.

The following installation assumptions were made:

1) The maximum diameter of the equipment inside the glovebox is 6 inches, nominal.

2) The spacing (criticality prevention) between each piece of equipment is about 18 inches and the spacing between an accessible edge of the glovebox and any piece of equipment is about 8 inches.

3) The cost of connecting lines from plant air, reagent tanks (nitric acid solution, etc.), electrical, process waste line, and the offgas (to existing process vacuum) to the equipment inside the glovebox will be similar for all the identified gloveboxes.

4) The product will be transferred to a staging tank in HC-227S (an intermediate tank used to store product after pretreatment prior to sending it to the vertical calciner process).

5) The storage container liquid retrieval ( $P R$ can and other container unloading) station will be at $\mathrm{HC}-227 \mathrm{~S} / \mathrm{T}$.

6) The glovebox exhaust ventilation and process vessel vent will be routed to the existing PFP E-4 filter room(s) (Rooms 309 \& 310), through an existing filter box, via E-4 HVAC piping in the duct leve?.

7) The pretreatment waste from the collection tanks will be connected to a drain line which will route plant liquid wastes to TK-08, 241-Z.

8) For $\mathrm{HC}-7 \mathrm{C}$, the reagent lines run from Room $336 / 337$ (top level) to the duct level and are connected to the pretreatment vessels inside the giovebox. For the HA-46 glovebox and mini-canyon, the reagent 1 ines 
will be reconnected from Rooms $336 / 337$, to vesse]s/equipment inside the mini-canyon or inside the HA-46 glovebox.

9) The glovebox shall be at least 5 feet tall to allow enough space for the pretreatment column and for maintenance.

10) Lag and product storage is dependent on the vessels in $\mathrm{HC}-227 \mathrm{~S}$ which contains 3 batch tanks of $40 \mathrm{~L}$ each and 2 receiving tanks of $20 \mathrm{~L}$ each. Feed storage required is at least $14 \mathrm{~L}$.

\subsection{METHODOLOGY}

The selected gloveboxes will be compared in the following areas which are listed in order of relative importance.

1) criticality safety,

2) ALARA,

3) security and safeguards,

4) cost of installation of new equipment (estimated),

5) ease of installation of the equipment,

6) access to storage vessel liquid retrieval station, and

7) availability of plant services.

\subsection{EVALUATION OF GLOVEBOXES}

5.1 Gloveboxes Eliminated. Most of the gloveboxes at the Plutonium Finishing Plant were eliminated from detailed consideration based on various limitations for the pretreatment process. Gloveboxes eliminated include:

1) Existing gloveboxes in the Plutonium Reclamation Facility (PRF) area were el iminated as a potential site because Terminal Clean Out (TCO) of that process area will overlap the pretreatment operation.

2) Existing gloveboxes in the Remote Mechanical A (RMA) 1 ine area were eliminated as potential sites due to high dose rates in this area.

3) The RMA Line fabrication area (lower dose rate) in room $235 \mathrm{~B}$ and $\mathrm{C}$ has gloveboxes that were eliminated from consideration for the pretreatment process. Most of these gloveboxes are too small or they are being considered for other processes. Also, solution is hardly ever introduced into this area and longer transfer lines would be required for the reagent addition lines. 
4) The gloveboxes in the Plutonium Process Support Laboratory (PPSL) and the Analytical Laboratory was el iminated due to a need for a security upgrade, transfer lines, and operations interfering in laboratory processes.

5) The gloveboxes in the RADTU were el iminated due to large volumes of equipment needing removal from the gloveboxes and the lack of access to the gloveboxes (no ports or air locks).

6) Installation of the IX column in Room 232A (HC-46 mini-canyon) was eliminated due to the need to remove some of the pencil tanks and the $\mathrm{HF}$ scrubber as well as 1 imited gloveport access.

7) The gloveboxes in Rooms 166, 169, and 170 were eliminated due to Radiological Sabotage concerns as these rooms are on an exterior wall of the building.

5.2 Gloveboxes Considered. The Plutonium Finishing Plant Processing Gloveboxes considered for installation of the pretreatment process include the following:

1) The gloveboxes in the RMC Line were evaluated as a potential site for the pretreatment process (preferred due to one additional wall between the process area and the non-radiological area for containment control in the case of an abnormal occurrence). RMC 1 ine gloveboxes $\mathrm{HC}-7 \mathrm{C}$ and $\mathrm{HC}-15$ located in Rooms $228 \mathrm{~A}$ and $228 \mathrm{~B}$ respectively were large enough to be considered for installation of the pretreatment process.

2) G1ovebox HA-46 (1ocated in room 232) was considered for installation of the pretreatment process.

3) A new glovebox (7ocated in room $228 \mathrm{~B}$ or room 232) was considered for installation of the pretreatment process.

\subsection{Description of the Gioveboxes}

Glovebox HC-7C: The overall size of this glovebox is 8 feet long by 4 feet deep by 10 feet high. See Figure 2 or drawing no. H-2-19260 for details. There is sufficient space to install all the equipment inside this glovebox. Glovebox $\mathrm{HC}-7 \mathrm{C}$ contains contaminated equipment including tanks, pipelines, tubing, tubing fittings, valves, piping fittings, and instrument connections.

Glovebox HC-15: This glovebox is sectioned into three equal parts. Each part is 2 feet 8 inches wide by 2.5 feet deep by 6.25 feet high. The overall size of this glovebox is 8 wide by 2.5 feet deep by 6.25 feet high. There is sufficient space to install all the equipment inside this glovebox. Glovebox HC-I5A, B, C contains contaminated equipment including reduction furnaces, hydraulic rams in floor, tubing, and tubing fittings. 
Glovebox HA-46: The overall size of this glovebox is 7 feet 5 inches 7 ong by 1 foot 9 inches deep (acceptable due to single side access) by 13 feet 9 inches high. See Figure 3 or drawing no. H-2-27354 for details. There is sufficient space to install all the equipment inside this glovebox. Glovebox HA-46 contains contaminated equipment including tanks, pipelines, tubing, tubing fittings, valves, piping fittings, and instrument connections.

New Glovebox: The overall size of this glovebox will allow for criticality spacing of the pretreatment column and adequate tankage for the feed tanks and eluate collection tanks. The minimum size of the giovebox is approximately 5.5 feet long by 1 foot 10 inches deep (two sided access) by 5 feet high.

Glovebox $\mathrm{HC}-15$ was eliminated after considering the following:

1) There is currently no chemical (nitric acid, etc.) supply lines to the glovebox.

2) The update to the criticality safety analysis would require adding liquid processing and a criticality drain.

3) Equipment removal would include the three reduction furnaces, the argon supply, and a large off-gas system.

4) Installation would include placing the new column and vessels in the openings left by the reduction furnaces.

5) New transfer lines need to be installed from HC-227S to the glovebox, from the glovebox to the vertical calciner, and from this glovebox to the waste tanks.

6) The glovebox is deep orientated which does not allow for good glove access.

7) The polycube pyrolysis process equipment may be installed in this glovebox.

\subsection{Evaluation Against Criteria}

Table 1 1 ists the evaluations of gloveboxes $\mathrm{HC}-7 \mathrm{C}$ and $\mathrm{HA}-46$ and Table 21 ists the evaluations of the new glovebox installed in Room $228 \mathrm{~B}$ or 232 against the various criteria. The table also includes a qualitative score for the Gloveboxes based on the evaluation. A weighing factor was given to each criteria, and a total weighted score obtained. 


\begin{tabular}{|c|c|c|c|c|c|c|c|}
\hline \multicolumn{2}{|c|}{ Area of Comparison } & $\mathrm{HC}-7 \mathrm{C}$ & score & $\begin{array}{l}\text { score } x \\
\text { weigh. } \\
\text { factor }\end{array}$ & $\mathrm{HA}-46$ & Score & $\begin{array}{l}\text { Score } x \\
\text { weigh. } \\
\text { factor }\end{array}$ \\
\hline 1. & $\begin{array}{l}\text { Process } \\
\text { Interaction }\end{array}$ & $\begin{array}{l}\text { The air space of room } 227 \text { which may go } \\
\text { on mask dur ing load out of pretreatment } \\
\text { feed solutions could affect the air } \\
\text { space of Room } 228 \text { (go on mask) where HC- } \\
\text { 7C is lacated. }\end{array}$ & 4 & 16 & $\begin{array}{l}\text { Roon } 232 \text { has a separate air } \\
\text { space from room } 227 \text { and no } \\
\text { other act ive processes } \\
\text { operating. }\end{array}$ & 8 & 32 \\
\hline 2. & $\begin{array}{l}\text { Schedule } \\
\text { (transfer } \\
\text { lines) }\end{array}$ & $\begin{array}{l}\text { Transfer lines exist from } \mathrm{HC}-227 \mathrm{~S} \text { to } \mathrm{HC}- \\
7 \mathrm{C} \text {, and transfer tines exist from HC-7C } \\
\text { to the vertical denitrator calciner } \\
\text { (product staged in HC-227S tanks). }\end{array}$ & 8 & 48 & $\begin{array}{l}\text { Transfer lines from } \mathrm{HC}-227 \mathrm{~S} \\
\text { to } \mathrm{HA}-46 \text { and from } \mathrm{HA}-46 \text { to } \\
\text { the denitrator must be } \\
\text { installed. }\end{array}$ & 4 & 24 \\
\hline 2.1 & $\begin{array}{l}\text { Criticality } \\
\text { Analysis Done }\end{array}$ & $\begin{array}{l}\text { The update of the criticality safety } \\
\text { analysis would be facititated due to the } \\
\text { current criticality safety analysis } \\
\text { covering the presence of large } \\
\text { quantities of Pu-bearing liquid. A } \\
\text { criticality drain is present (no change } \\
\text { needed to FSAR). }\end{array}$ & . & 64 & $\begin{array}{l}\text { The last use of this } \\
\text { glovebox did not include } \\
\text { large amounts of Pu-bearing } \\
\text { liquid which would require } \\
\text { additional work during the } \\
\text { critical ity safety } \\
\text { analysis. Also, the sump } \\
\text { tank would need to be } \\
\text { blanked off. A criticality } \\
\text { drain woutd need to be } \\
\text { installed and the FSAR } \\
\text { updated. }\end{array}$ & 2 & 16 \\
\hline 2.2 & $\begin{array}{l}\text { Fire } \\
\text { Suppression } \\
\text { Installed }\end{array}$ & $\begin{array}{l}\text { Fire suppression is installed in this } \\
\text { glovebox. }\end{array}$ & 10 & 40 & $\begin{array}{l}\text { Fire suppression is not } \\
\text { installed in this glovebox. }\end{array}$ & 0 & 0 \\
\hline 2.3 & $\begin{array}{l}\text { Seismic } \\
\text { Analysis Done }\end{array}$ & $\begin{array}{l}\text { The seismic analysis is not done for } \\
\text { this glovebox, but the glovebox goes all } \\
\text { the way to the floor so implementation } \\
\text { of a seismic analysis will be } \\
\text { facilitated. }\end{array}$ & 8 & 32 & $\begin{array}{l}\text { The seismic analysis is not } \\
\text { done for this glovebox. The } \\
\text { glovebox is } 20 \text { inches off } \\
\text { the floor and the mini- } \\
\text { canyon contains tanks that } \\
\text { need to be seismically } \\
\text { evaluated. }\end{array}$ & 4 & 16 \\
\hline 2.4 & $\begin{array}{l}\text { Modifications } \\
\text { (Demolition) }\end{array}$ & $\begin{array}{l}\text { Removal of equipment includes one tank } \\
\text { and about } 20 \text { feet of piping. }\end{array}$ & 4 & 16 & $\begin{array}{l}\text { Renoval of equipment } \\
\text { includes removal of two } \\
\text { heat exchangers and about } \\
40 \text { feet of piping. }\end{array}$ & 2 & 8 \\
\hline 3. & $\begin{array}{l}\text { Size of } \\
\text { Glovebox } \\
\text { (Tankage) }\end{array}$ & $\begin{array}{l}\text { The glovebox is tall enough for the } \\
\text { pretreatment colum, but the vessels } \\
\text { that will be reused for the feed and } \\
\text { collection vessels are smaller than the } \\
\text { optimal volume. }\end{array}$ & 6 & 60 & $\begin{array}{l}\text { The glovebox is tall enough } \\
\text { for the pretreatment column } \\
\text { and the banks of pencil } \\
\text { tanks in the mini-canyon } \\
\text { can be used for feed and } \\
\text { collection vessels. }\end{array}$ & 8 & 80 \\
\hline
\end{tabular}




\begin{tabular}{|c|c|c|c|c|c|c|}
\hline Area of Comparison & $\mathrm{HC}-7 \mathrm{C}$ & Score & $\begin{array}{l}\text { Score } x \\
\text { weigh. } \\
\text { factor }\end{array}$ & $\mathrm{HA}-46$ & Score & $\begin{array}{l}\text { Score X } \\
\text { weigh. } \\
\text { factor }\end{array}$ \\
\hline $\begin{array}{l}\text { 4. Safeguards and } \\
\text { Security }\end{array}$ & $\begin{array}{l}\text { This glovebox is located in room } 228 \mathrm{~A} \text {, a } \\
\text { protected area, which has had a Risk } \\
\text { Analysis performed that can be updated. } \\
\text { For the HC-7C glovebox to be used for } \\
\text { the pre-treatment process, a } \\
\text { Vulnerabitity Assessment (VA) would need } \\
\text { to be done. }\end{array}$ & 8 & 64 & $\begin{array}{l}\text { This glovebox is located in } \\
\text { room } 232 \text {, not a protected } \\
\text { area, which has had no } \\
\text { vulnerabil ity Assessments } \\
\text { performed for operation of } \\
\text { Category } 1 \text { or } 2 \text { processes. } \\
\text { Therefore, an new risk } \\
\text { assessment would need to be } \\
\text { performed. }\end{array}$ & 2 & 16 \\
\hline 5. Utilities & $\begin{array}{l}\text { The following reagents are connected to } \\
\text { the glovebox: concentrated and dilute } \\
\text { nitric acid, and a hydrogen peroxide } \\
\text { line (reused by the eluant line). The } \\
\text { glovebox off-gas is connected. } \\
\text { Electricity is connected to the } \\
\text { glovebox. }\end{array}$ & 8 & 32 & $\begin{array}{l}\text { The following reagents were } \\
\text { connected to the glovebox: } \\
\text { concentrated and dilute } \\
\text { nitric acid (eluant make } \\
\text { up), and potassium } \\
\text { hydroxide. Ihe glovebox } \\
\text { off-gas is connected. } \\
\text { Electricity is connected to } \\
\text { the glovebox. }\end{array}$ & 5 & 20 \\
\hline $\begin{array}{l}\text { 6. ALARA } \\
\text { (Exposure) }\end{array}$ & $\begin{array}{l}\text { ALARA concerns are high during the } \\
\text { removal of contaninated material (seal } \\
\text { in and out) from the glovebox and during } \\
\text { the installation of the pretreatment } \\
\text { equipment in an area with } 1-12 \text { mrem/hr } \\
\text { dose rates. Under nornal operations this } \\
\text { glovebox wilt see higher dose rates than } \\
\text { HA-46 due to shine from other process. } \\
\text { See Appendix A for a dose map and dose } \\
\text { estimations due to differences in the } \\
\text { locations of the gloveboxes. }\end{array}$ & 4 & 40 & $\begin{array}{l}\text { ALARA concerns are high } \\
\text { during the removal of } \\
\text { contaminated material (seal } \\
\text { in and out) from the } \\
\text { glovebox and during the } \\
\text { installation of the } \\
\text { pretreatment equipment in } \\
\text { an area with } 0.5 \text { mrem/hr } \\
\text { dose rates. This glovebox } \\
\text { will not see higher dose } \\
\text { rates due to shine from } \\
\text { other processes. (See } \\
\text { Appendix A.) }\end{array}$ & 8 & 80 \\
\hline 7. Cost Estimation & $\begin{array}{l}\text { Qualitatively the work associated with } \\
\text { the removal and installation of new } \\
\text { equipment in the gloveboxes will be } \\
\text { similar for both gloveboxes. This } \\
\text { glovebox al ready has a fire suppression } \\
\text { system. Transfer lines from HC-227s to } \\
\text { this glovebox and to the vertical } \\
\text { denitrator (via HC-227s) already exist } \\
\text { and do not need to be installed. }\end{array}$ & 8 & 32 & $\begin{array}{l}\text { In addition to the } \\
\text { installation of the new } \\
\text { equipment, new transfer } \\
\text { lines from HC- } 227 \text { S and a } \\
\text { new fire suppression system } \\
\text { need to be installed. } \\
\text { Seismic analysis and } \\
\text { implementation, Safeguards } \\
\text { and Security analys is and } \\
\text { installation, and } \\
\text { criticality safety analysis } \\
\text { will be more costly. }\end{array}$ & 4 & 16 \\
\hline
\end{tabular}




\begin{tabular}{|c|c|c|c|c|c|c|c|}
\hline Area & of Comparison & $\mathrm{HC}-7 \mathrm{C}$ & Score & $\begin{array}{l}\text { Score } x \\
\text { Heigh. } \\
\text { factor }\end{array}$ & HA- 46 & Score & $\begin{array}{l}\text { Score } x \\
\text { weigh. } \\
\text { factor }\end{array}$ \\
\hline 8. & $\begin{array}{l}\text { Ease of } \\
\text { Installation }\end{array}$ & $\begin{array}{l}\text { Remove one tank and associated piping } \\
\text { and install a new column and associated } \\
\text { piping. Reuse } 3 \text { tanks and } 2 \text { pumps. }\end{array}$ & 8 & 32 & $\begin{array}{l}\text { Remove miscel laneous } \\
\text { equipment and install } \\
\text { colum with piping in this } \\
\text { glovebox and reuse tanks in } \\
\text { mini-canyon. }\end{array}$ & 4 & 16 \\
\hline 9. & $\begin{array}{l}\text { Access to } \\
\text { Liquid } \\
\text { Retrieval } \\
\text { Station }\end{array}$ & $\begin{array}{l}\text { Existing transfer lines. Glovebox is } 15 \\
\text { ft from retrieval station. }\end{array}$ & 8 & 48 & $\begin{array}{l}\text { Install new transfer lines. } \\
\text { Glovebox is } 30 \mathrm{ft} \text { from the } \\
\text { retrieval station. }\end{array}$ & 4 & 24 \\
\hline 10.1 & $\begin{array}{l}\text { Raffinate } \\
\text { Collection }\end{array}$ & $\begin{array}{l}\text { Double encased lines to the HA- } 46 \\
\text { glovebox exist from HC-7C but double } \\
\text { encased } 1 \text { ines from the HA- } 46 \text { glovebax to } \\
\text { the raffinate collection tanks in the } \\
\text { HA }-46 \text { mini-canyon do not exist and will } \\
\text { need to be installed. }\end{array}$ & 7 & 28 & $\begin{array}{l}\text { Double encased transfer } \\
\text { lines fron the HA- } 46 \\
\text { glovebox to raffinate } \\
\text { collection tanks in the HA- } \\
46 \text { mini-canyon do not exist } \\
\text { for this glovebox and need } \\
\text { to be installed. }\end{array}$ & 9 & 36 \\
\hline 10.2 & Waste Routing & $\begin{array}{l}\text { New drain line to pipe turnels needs to } \\
\text { meet dangerous waste pipe inspection } \\
\text { criteria which is: detect in } 24-h r \\
\text { period by 1) visual or 2) leak } \\
\text { detection. }\end{array}$ & 4 & 24 & $\begin{array}{l}\text { MeH drain line meets same } \\
\text { inspection criteria as } \mathrm{HC}- \\
7 \mathrm{C} \text {. }\end{array}$ & 4 & 24 \\
\hline \multicolumn{2}{|l|}{ Total } & & & 576 & & & 412 \\
\hline
\end{tabular}

1. Process Interaction

2. Schedule

2.1 Criticality Safety Done

2.2 Fire Suppression Installed

2.3 Seismic Analysis Done

2.4 Modifications (Demolition)

3. Size of Glovebox (Tankage)

4. Security and Safeguards
5. Utilities

6. ALARA

7. Cost Estimation

8. Ease of Installation

9. Access to Liquid Retrieval Station

10.1 Raffinate Collection

10.2 Waste Routing
4

10

4

4

6

4 


\begin{tabular}{|c|c|c|c|c|c|c|}
\hline Area of Comparison & New Glovebox installed in Room 228B & Score & $\begin{array}{l}\text { Score } x \\
\text { weigh. } \\
\text { factor }\end{array}$ & Hew Glovebox installed in Room 232 & Score & $\begin{array}{l}\text { Score } X \\
\text { weigh. } \\
\text { factor }\end{array}$ \\
\hline $\begin{array}{l}\text { 1. Process } \\
\text { interaction }\end{array}$ & $\begin{array}{l}\text { The air space of room } 227 \text { which may go on } \\
\text { mosk during load out of pretreatment } \\
\text { solutions could affect the air space of } \\
\text { Room } 2283 \text { (go on mask) where this new } \\
\text { glovebox is located. }\end{array}$ & 6 & 24 & $\begin{array}{l}\text { Room } 232 \text { has a separate air space } \\
\text { from room } 227 \text { and no other active } \\
\text { processes operating. }\end{array}$ & 8 & 32 \\
\hline $\begin{array}{l}\text { 2. Schedule } \\
\text { (transfer lines) }\end{array}$ & $\begin{array}{l}\text { Iransfer lines from } H C-227 S \text { to the new } \\
\text { glovebox and from the new glovebox to the } \\
\text { denitrator must be installed. }\end{array}$ & 4 & 24 & $\begin{array}{l}\text { Transfer lines from HC-227s to the } \\
\text { new glovebox and from the new } \\
\text { glovebox to the denitrator must be } \\
\text { installed. }\end{array}$ & 4 & 24 \\
\hline $\begin{array}{r}2.1 \text { Criticality } \\
\text { Analysis Done } \\
\end{array}$ & $\begin{array}{l}\text { A new criticality safety analysis will } \\
\text { need to be done. }\end{array}$ & 4 & 32 & $\begin{array}{l}\text { A new criticality safety analysis } \\
\text { will need to be done. }\end{array}$ & 4 & 32 \\
\hline $\begin{array}{l}2.2 \text { Fire } \\
\text { Suppression } \\
\text { Installed }\end{array}$ & $\begin{array}{l}\text { Fire suppression would need to be } \\
\text { installed in this glovebox. }\end{array}$ & 0 & 0 & $\begin{array}{l}\text { Fire suppression would need to be } \\
\text { installed in this glovebox. }\end{array}$ & 0 & 0 \\
\hline $\begin{array}{l}2.3 \text { Seismic } \\
\text { Analysis Done } \\
\end{array}$ & $\begin{array}{l}\text { The seismic analysis would need to be done } \\
\text { for this glovebox. }\end{array}$ & 6 & 24 & $\begin{array}{l}\text { The seismic analysis would need to } \\
\text { be done for this glovebox. }\end{array}$ & 6 & 24 \\
\hline $\begin{array}{l}2.4 \text { Modifications } \\
\text { (Demolition) }\end{array}$ & $\begin{array}{l}\text { No removal of equipment required. } \\
\text { Fabricate and install end plates. }\end{array}$ & 10 & 40 & $\begin{array}{l}\text { No removal of equipment required. } \\
\text { Fabricate and install end plates. }\end{array}$ & 10 & 40 \\
\hline $\begin{array}{l}\text { 3. Size of Glovebox } \\
\text { (Tankage) }\end{array}$ & $\begin{array}{l}\text { The glovebox is tall enough for the } \\
\text { pretreatment process equipment and the } \\
\text { desired feed and product collection } \\
\text { tankage. }\end{array}$ & 4 & 40 & $\begin{array}{l}\text { The glovebox is big enough for the } \\
\text { pretreatment process equipment and } \\
\text { the desired feed and product } \\
\text { collection tankage. }\end{array}$ & 4 & 40 \\
\hline $\begin{array}{l}\text { 4. Safeguards and } \\
\text { Security }\end{array}$ & $\begin{array}{l}\text { This glovebox is located in room } 228 B \text {, a } \\
\text { protected area, which has had a Risk } \\
\text { Analysis performed. For the new glovebox } \\
\text { to be used for the pre-treatment process, } \\
\text { a vulnerability Assessment (VA) would need } \\
\text { to be done. }\end{array}$ & 6 & 48 & $\begin{array}{l}\text { If this glovebox is located in room } \\
232 \text {, not a protected area, then a } \\
\text { Vulnerability Assessment needs to be } \\
\text { performed for operation of Category } \\
1 \text { or } 2 \text { processes. }\end{array}$ & 2 & 16 \\
\hline 5. Utilities & $\begin{array}{l}\text { All utilities would need to be connected } \\
\text { to this glovebox. }\end{array}$ & 4 & 16 & $\begin{array}{l}\text { All utilities would need to be } \\
\text { connected to this glovebox. }\end{array}$ & 4 & 16 \\
\hline
\end{tabular}




\begin{tabular}{|c|c|c|c|c|c|c|}
\hline Area of Comparison & New Glovebox installed in Room 228B & Score & $\begin{array}{l}\text { Score } X \\
\text { weigh. } \\
\text { factor }\end{array}$ & New Glovebox installed in Room 232 & Score & $\begin{array}{l}\text { Score } x \\
\text { weigh. } \\
\text { factor }\end{array}$ \\
\hline 6. ALARA (Exposure) & $\begin{array}{l}\text { No ALARA concerns during the installation } \\
\text { of the pretreatment process equipment. } \\
\text { Some ALARA concerns during the connection } \\
\text { of the off-gas and reagent lines to the } \\
\text { glovebox. }\end{array}$ & 8 & 80 & $\begin{array}{l}\text { No ALARA concerns during the } \\
\text { installat } i \text { on of the pretreatment } \\
\text { process, equipment. Some ALARA } \\
\text { concerns during the connection of } \\
\text { the off-gas and reagent lines to the } \\
\text { glovebox. }\end{array}$ & 8 & 80 \\
\hline 7. Cost Est imation & $\begin{array}{l}\text { The work associated with the installation } \\
\text { of new equipment in this glovebox hould } \\
\text { cost less than the removal and } \\
\text { installation of equipment in HC-7C or HA- } \\
46 \text {. Connection of this glovebox to the } \\
\text { off-gas, reagents, and utilities would } \\
\text { cost more than the other two gloveboxes. } \\
\text { In addition to the installation of the new } \\
\text { equipment, new transfer lines from HC-227S } \\
\text { and a new fire suppression system need to } \\
\text { be installed. Seismic analysis and } \\
\text { implementation, Safeguards and Security } \\
\text { analysis and installation, and Criticality } \\
\text { Safety analysis would be more costly. }\end{array}$ & 6 & 24 & $\begin{array}{l}\text { The work associated with the } \\
\text { installation of new equipment in } \\
\text { this glovebox would cost less than } \\
\text { the removal and installation of } \\
\text { equipment in HC-7C or HA- } 46 \text {. } \\
\text { Connection of this glovebox to the } \\
\text { off-gas, reagents, and utilities } \\
\text { would cost more than the other two } \\
\text { gloveboxes. In addition to the } \\
\text { installation of the new equipment, } \\
\text { new transfer lines from HC-227s and } \\
\text { a new fire suppression system needs } \\
\text { to be installed. Seismic analysis } \\
\text { and implementation, Safeguards and } \\
\text { Security analysis and installation, } \\
\text { and Criticality Safety analysis } \\
\text { woutd be more costly. }\end{array}$ & 4 & 16 \\
\hline $\begin{array}{l}\text { 8. Ease of } \\
\text { Installation }\end{array}$ & $\begin{array}{l}\text { Installation will be facilitated by the } \\
\text { glovebox being free of contamination. }\end{array}$ & 10 & 40 & $\begin{array}{l}\text { Installation will be facilitated by } \\
\text { the glovebox being free of } \\
\text { contamination. }\end{array}$ & 10 & 40 \\
\hline $\begin{array}{l}\text { 9. Access to Liquid } \\
\text { Retrieval station }\end{array}$ & $\begin{array}{l}\text { Install new transfer lines. Glovebox is } \\
60 \mathrm{ft} \text { from the retrieval station. }\end{array}$ & 2 & 12 & $\begin{array}{l}\text { Install new transfer lines. Glovebox } \\
\text { is } 40 \mathrm{ft} \text { from the retrieval station. }\end{array}$ & 4 & 24 \\
\hline $\begin{array}{l}\text { 10.1 Raffinate } \\
\text { Collection }\end{array}$ & $\begin{array}{l}\text { Double encased lines to raffinate } \\
\text { collection in the HA- } 46 \text { mini-canyon do not } \\
\text { exist for this glovebox and would need to } \\
\text { be installed. }\end{array}$ & 2 & 8 & $\begin{array}{l}\text { Double encased lines to raffinate } \\
\text { collection in the HA- } 46 \text { mini-canyon } \\
\text { do not exist for this glovebox. }\end{array}$ & 5 & 20 \\
\hline
\end{tabular}




\begin{tabular}{|c|c|c|c|c|c|c|}
\hline Area of Comparison & Hew Glovebox installed in Room $228 \mathrm{~B}$ & Score & $\begin{array}{l}\text { Score } K \\
\text { weigh. } \\
\text { factor }\end{array}$ & New Glovebox installed in Room 232 & Score & $\begin{array}{l}\text { Score } X \\
\text { weigh. } \\
\text { factor }\end{array}$ \\
\hline 10. Waste Routing & $\begin{array}{l}\text { New drain line to pipe tunnels needs to } \\
\text { meet dangerous waste pipe inspection } \\
\text { criteria which is: detect in } 24-h r \text { period } \\
\text { by 1) visual or 2) leak detection. }\end{array}$ & 4 & 24 & $\begin{array}{l}\text { Hew drain (ine to pipe tunnels needs } \\
\text { to meet dangerous waste pipe } \\
\text { inspection criteria which is: detect } \\
\text { in } 24-\mathrm{hr} \text { period by 1) visual or } 2 \text { ) } \\
\text { leak detection. }\end{array}$ & 4 & 24 \\
\hline Total & & & 436 & & & 428 \\
\hline
\end{tabular}

Scoring: The above areas in Table 2 were evaluated on a scale of 1 to 10 (10 being a perfect score). Those scores were then multiplied by the following weighing factors

$\begin{array}{lllll}\text { 1. } & \text { Process Interaction } & 4 & 5 . & \text { Utilities } \\ \text { 2. } & \text { Schedule } & 6 & 6 . & \text { ALARA } \\ \text { 2.1 } & \text { Criticality Safety Done } & 8 & 7 . & \text { Cost Estimation } \\ \text { 2.2 } & \text { Fire Suppression Installed } & 4 & 8 . & \text { Ease of Installation } \\ \text { 2.3 } & \text { Seismic Analysis Done } & 4 & 9 . & \text { Access to Liquid Retrieval Station } \\ \text { 2.4 Modifications (Demolition) } & 4 & 10.1 & \text { Raffinate Collection } \\ \text { 3. Size of Glovebox (Tankage) } & 10 & 10.2 & \text { Waste Routing } \\ \text { 4. Security and Safeguards } & 8 & & \end{array}$




\subsection{Additional Information:}

5.5.1 Security and safeguards: Glovebox HC-7C: This glovebox is located in room $228 \mathrm{~A}$, a protected area, which has had a Risk Analys is performed. For the HC-7C glovebox to be used for the pre-treatment process, a Vulnerability Assessment would need to be done. The security upgrades required as a resuit of the engineering review could result in the repositioning of the existing motion detection or additional motion detection coverage of the new target areas. The cost of the review and resulting security upgrades could be significant, and the cost cannot be determined until the engineering review is complete. As a result of other security assessments (for 94-1 work), the exterior doors to 228A are already being upgraded. This door upgrade could speed the implementation of the necessary security upgrades for this room.

Glovebox HA-46: This glovebox is located in room 232, not a protected area, which has had no Risk Analysis performed for operation of Category 1 or 2 processes. The Risk Anatysis would need to be performed and sent to DOE which could take many months of preparation and review. The Risk Analysis and Engineering review could require significant security upgrades which might include installing motion detectors, upgrading doors, and etc.

New Glovebox: If this glovebox is located in room 232, not a protected area, then this room has had no Risk Analysis performed for operation of Category 1 or 2 processes. The Risk Analysis would need to be performed and sent to DOE which could take many months of preparation and review. The Risk Analysis and Engineering review could require significant security upgrades which might include installing motion detectors, upgrading doors, and etc. If this glovebox is located in room 228B, a protected area, then this room has had a Risk Analysis performed. For the new glovebox to be used for the pre-treatment process, a Vulnerability Assessment would need to be done. The security upgrades required as a result of the engineering review could result in the repositioning of the existing motion detection or additional motion detection coverage of the new target areas. The cost of the review and resulting security upgrades could be significant, and the cost cannot be determined until the engineering review is complete.

5.5.2 Ease of Installation: Glovebox HC-7: To accommodate the new pretreatment equipment, the following equipment needs to be removed:

1) Filtrate storage tank,

2) less than 100 Linear feet of piping and tubing and its accessories.

The following existing equipment can be used to support the system:

1) The staging feed tank can be substituted by the existing Pre-Reduction tank (PRT) with moderate piping changes. 
2) The Eluate Recejving and Adjustment Tanks can be substituted by the existing Filtrate Kill tank (FKT) and Filtrate Catch tank (FCT).

3) The feed tank can be substituted by the existing Transfer Head Tank (THT), with minor piping changes.

4) The Aqueous Collection Tank (ACT) and the Flush Tank (FT) can be used to support the pretreatment process.

The existing contaminated equipment needing removal will be bagged out and disposed off as contaminated waste. This equipment must have the residual 1 iquid drained. Utilizing the existing equipment as mentioned above will require the same follow up procedure for draining and flushing.

The interior surface of this glovebox and the existing equipment are contaminated. Precautionary steps to prevent the spread of contamination need to be taken during the removal of the unnecessary equipment, the reuse of the existing equipment, and installation of the new equipment. This work will be done under contamination prevention control and thus will require a longer time to accomplish than an uncontaminated glovebox.

The availability of a nearby control room could be satisfied by using the RMC line control room since it contains shielding and viewing windows of this glovebox.

Glovebox HA-46: The current equipment needs to be removed possibly using a panel change at the top of the glovebox. This glovebox has two heat exchangers and approximately 40 feet of piping that need to be removed.

New Glovebox: The glovebox will be clean allowing unrestricted access during installation.

5.5.3 Utilities and Connections. Glovebox HC-7C: The following reagents are connected to the glovebox: concentrated and dilute nitric acid, hydrogen peroxide line (reused by the eluant line), and Potassium Permangenate (not reused). The glovebox off-gas is connected and it will be used for both process and glovebox off-gas. Electricity is connected to the glovebox. The glovebox has two 15 inch ports (no airlocks).

Glovebox HA-46: The following reagents were connected to the glovebox: concentrated and dilute nitric acid, and a potassium hydroxide line. The glovebox off-gas is connected and it will be used for both process. and glovebox off-gas. Electricity is connected to the glovebox.

The glovebox has two 15 inch ports (no airiocks). The sump tank would need to be blanked off.

New Glovebox: No connections are made to this glovebox. 
5.5.4 Waste Disposal Path. Process drain lines from the raffinate collection tanks must meet dangerous waste regulations which require visual inspection of waste line or double containment with leak detection.

\subsection{ADVANTAGES AND DISADVANTAGES}

The advantages and disadvantages of the gloveboxes considered for pretreatment installation follow:

Glovebox $\mathrm{HC}-7 \mathrm{C}$

Advantages:

- reagents piped to the glovebox,

- not being used for another process,

- tanks that can be reused,

- double encased lines connected to the raffinate collection area,

- existing double encased transfer lines to the denitrator via HC-227S,

- connected to reagent area,

- connected to the offgas system, and

- fire suppression installed.

Disadvantages:

- removar of contaminated equipment,

- room air flow problems (possibly on mask during load-out in HC-227S).

Glovebox HA-46:

Advantages:

- use the tanks in the HA-46 mini-canyon for feed staging (two pencil tank banks of $100 \mathrm{~L}$ each) and for waste handling (two pencil tank banks of $50 \mathrm{~L}$ each), and

- reagents (nitric acid, etc.) can be reconnected to the glovebox.

Disadvantages:

- contaminated equipment to be removed from the glovebox, and

- feed 7 ines from $\mathrm{HC}-2275$ need to be instajled. 
New GTovebox in Room 228B:

Advantages:

- if the new glovebox is installed in Room 228B, the transfer of product solution to the vertical denitrator would be a shorter distance than a glovebox in Room 232 (new glovebox or HA-46) or glovebox $\mathrm{HC}-7 \mathrm{C}$, and

- no equipment needs to be removed from the glovebox (install new equipment under clean conditions),

Disadvantages:

- available gloveboxes at FEMF must be removed from an existing glovebox line and end pieces fabricated and placed on the ends of the glovebox,

- raffinate collection lines need to be installed,

- fire suppression needs to be installed and connected to plant system, and - utilities need to be connected (off-gas, electrical, water piped to the glovebox, etc.) to plant systems.

New Glovebox in Room 232:

Advantages:

- if the new glovebox is installed in Room 232, then use the tanks in the HA-46 minicanyon for feed staging (two pencil tank banks of $100 \mathrm{~L}$ each) and for waste handling (two pencil tank banks of $50 \mathrm{~L}$ each), and

- no equipment needs to be removed from the glovebox (install new equipment under clean conditions),

Disadvantages:

- available gloveboxes at FEMF must be removed from an existing glovebox line and end pieces fabricated and placed on the ends of the glovebox,

- raffinate collection lines need to be installed,

- fire suppression needs to be installed and connected to plant system, and - utilities need to be connected (off-gas, electrical, water piped to the glovebox, etc.) to plant systems. 


\subsection{CONCLUSIONS AND RECOMMENDATIONS}

There is sufficient space in $\mathrm{HC}-7 \mathrm{C}, \mathrm{HA}-46$, and the new glovebox to install the process equipment, and provide for and maintain favorable geometry for criticality requirements. As seen in Tables 1 and 2, Glovebox $H C-7 C$ with 576 points is the most favorable of the locations evaluated. Glovebox $\mathrm{HC}-7 \mathrm{C}$ is recommended for installation of the pretreatment process. 


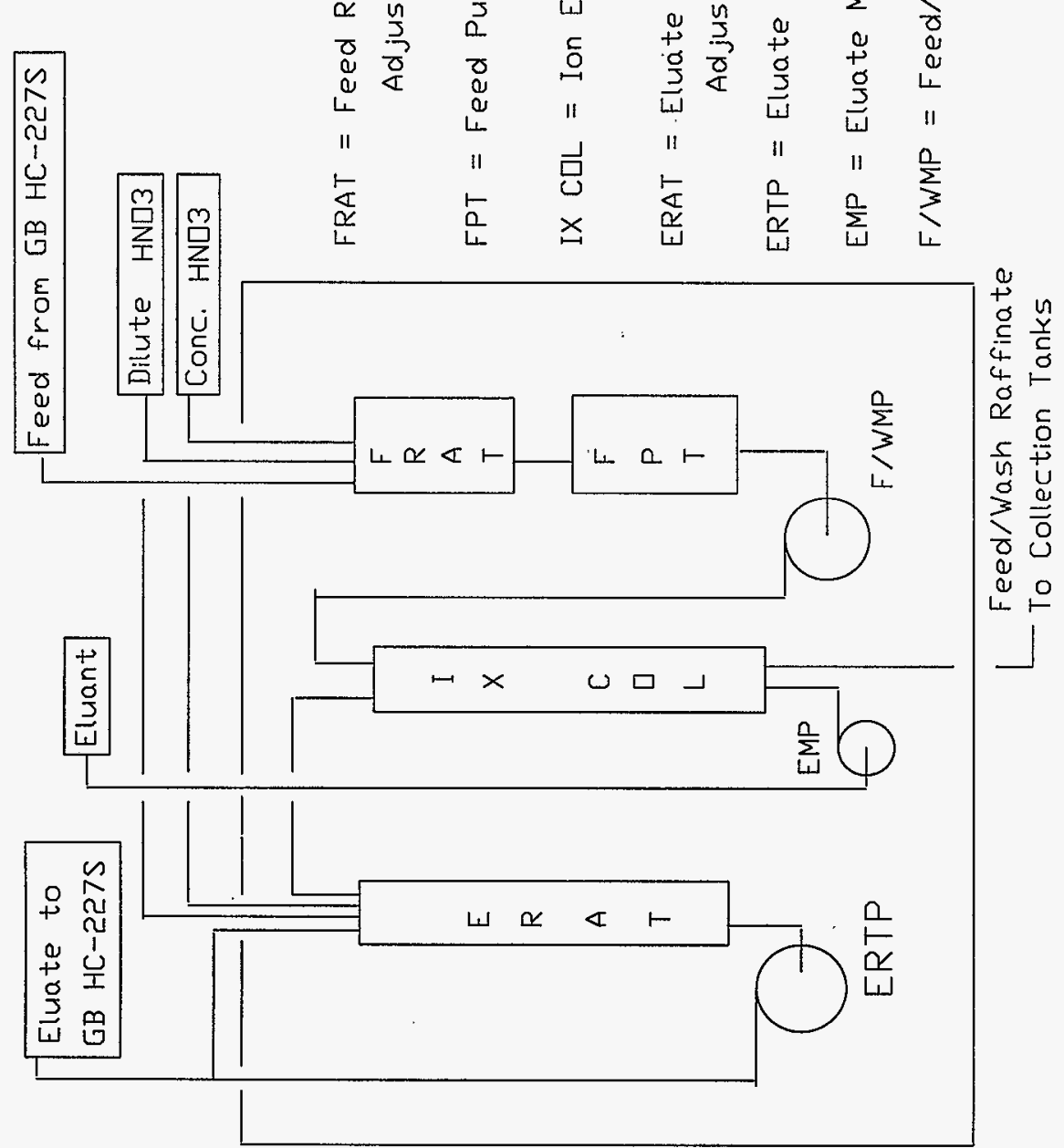




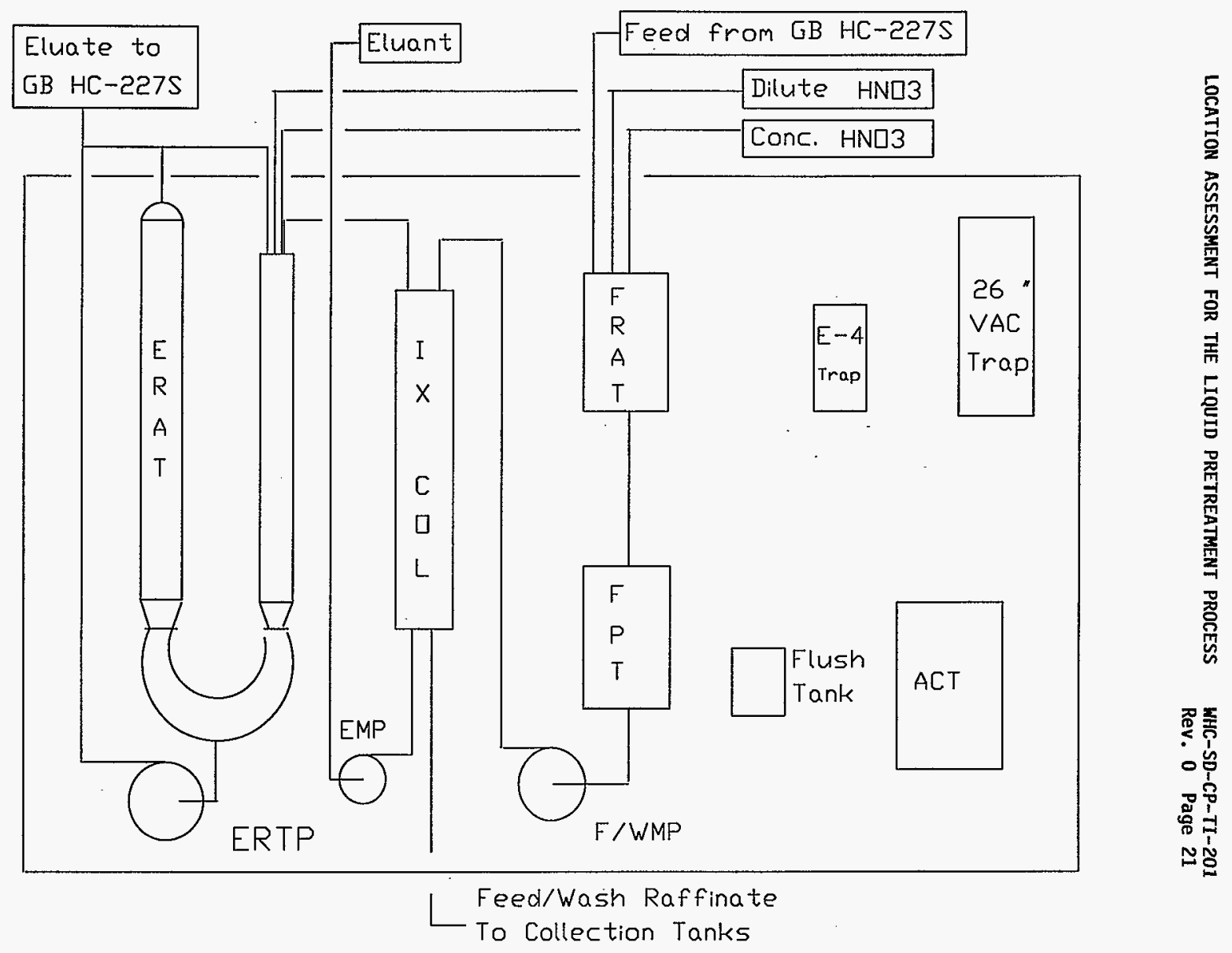

Figure 2. Pretreatment in the $\mathrm{HC}-7 \mathrm{C}$ Glovebox 


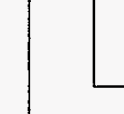 \\ UoKuoว-!U!W}

II

L
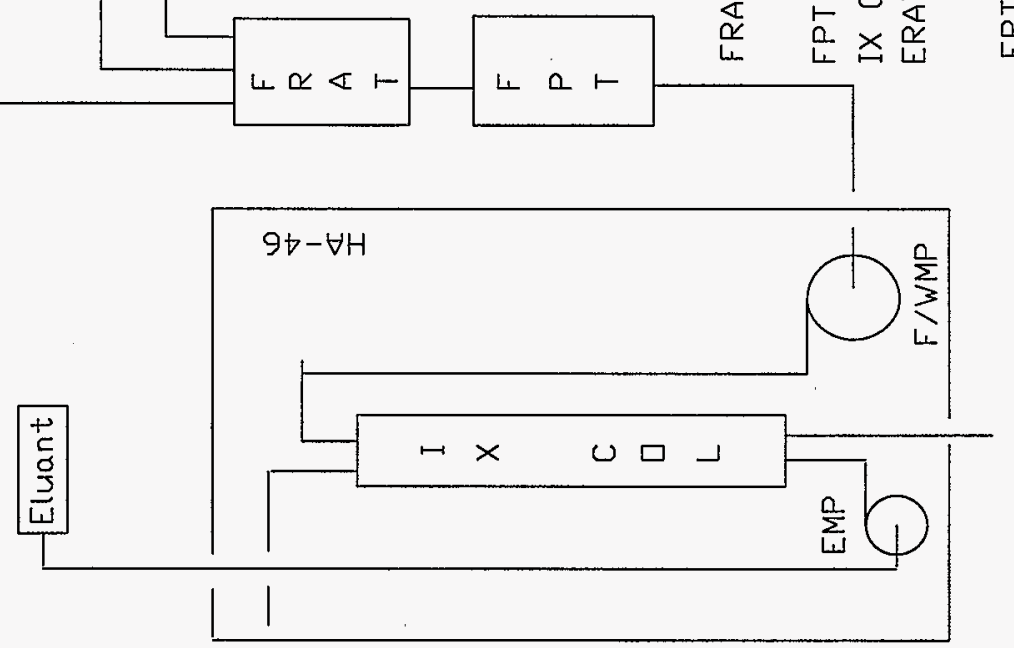

$\stackrel{a}{+}$

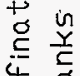

4 인

$\begin{array}{ccc}4 & 0 \\ \alpha & 0 & 0 \\ \alpha & \frac{1}{4}\end{array}$

in 0

U U

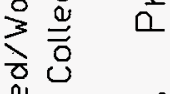

a $\mathrm{r}$

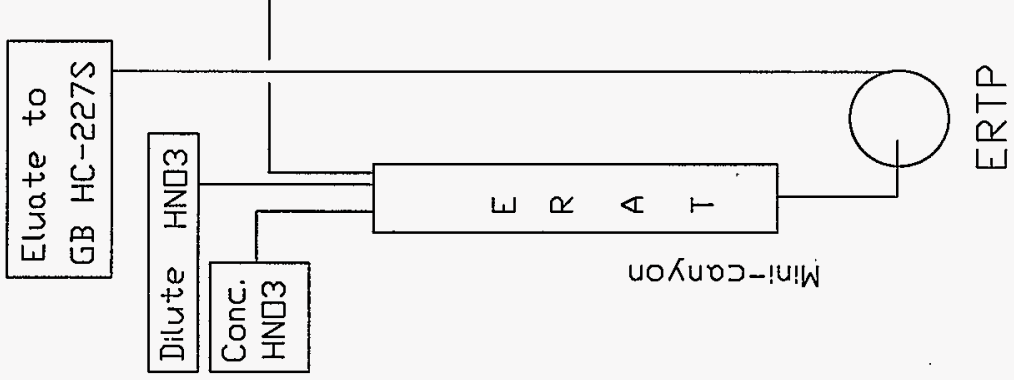




\section{APPENDIX A ALARA CONSIDERATIONS}

Differences in Dose from operation of the pretreatment process in different locations.

The total solution to be processed through pretreatment process (estimated in the EIS) is $2560 \mathrm{~L}$. There are $24.2 \mathrm{~L}$ processed per cycle (estimated in the EIS). Therefore, there will be 106 cycles required to process the solution.

Cycle time (from the EIS) includes:

$\begin{array}{ll}\text { Load the column } & 0.8 \mathrm{hr} \\ \text { Wash the column } & 1.0 \mathrm{hr} \\ \text { Elute the column } & 2.9 \mathrm{hr} \\ \text { Recondition the column } & \frac{0.3 \mathrm{hr}}{5.0 \mathrm{hr}} \\ \text { Total } & 5.04\end{array}$

Each Cycle will equal approximately one shift.

Therefore, 106 cycles equals 106 shifts. Assume 0.7 TOE, therefore $106 / 0.7=151$ shifts with 3 shifts per day $=50$ days which is approximately a 2 month campaign.

It is estimated that the operators will be near the operating glovebox for 1.5 hrs (1.0 hr equipment manipulation and $0.5 \mathrm{hr}$ surveillance) during each shift. It is assumed there will be two operators present during those times $1.5 \times 2=$ 3 hrs per shift.

The dose calculated below does not include actual dose from new Pu introduced into the IX system as this dose will be the same for all locations. The dose calculated below also does not include actual dose from load in of the solution from the PR cans into the vessels in glovebox $\mathrm{HC}-227 \mathrm{~S}$ and transfer of solution to the glovebox which will require 1 to 1.5 shifts to perform. The dose calculated below is due to the different locations of the gloveboxes relative to the amount of $\mathrm{Pu}$ currently present in the system, areas, and gloveboxes.

$\mathrm{HC}-7 \mathrm{C}$

Average dose around this glovebox is $8 \mathrm{mr} / \mathrm{hr}$ (shine from $\mathrm{HC}-1$ ).

Time: $\quad 1.5$ hrs per shift

People: 2

Rate: $\quad 8 \mathrm{mr} / \mathrm{hr}$

Dose: 24 pmr per shift

151 shifts per campaign or 3624 total pmr 
$\mathrm{HA}-46$

Average dose around this glovebox is $<0.5 \mathrm{mr} / \mathrm{hr}$.

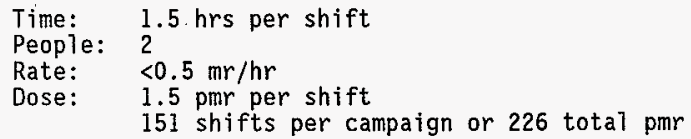

New Glovebox in Ro,om 232

Average dose around this glovebox is $<0.5 \mathrm{mr} / \mathrm{hr}$.

Time: $\quad 1.5$ hrs per shift

People: 2

Rate: $\quad<0.5 \mathrm{mr} / \mathrm{hr}$

Dose: 1.5 pmr per shift

151 shifts per campaign or 226 total pmr

New Glovebox in Room 228B

Average dose around this glovebox is $4 \mathrm{mr} / \mathrm{hr}$ (shine from $\mathrm{HC}-15$, etc.).

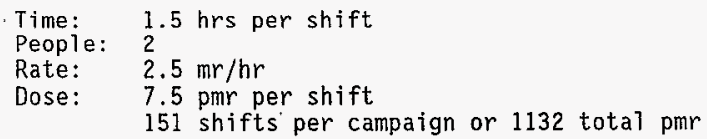

Dose from Demolition of existing equipment.

$\mathrm{HC}-7 \mathrm{C}$

Take hot feed filter out of $\mathrm{HC}-7 \mathrm{C}$.

$\begin{array}{ll}\text { Time } & 30 \mathrm{~min} . \\ \text { People } & 2 \\ \text { Rate } & 100 \mathrm{mr} / \mathrm{hr} \\ \text { Dose } & 100 \mathrm{pmr}\end{array}$


Remove FST from glovebox.

$\begin{array}{ll}\text { Time } & 8 \mathrm{hr} . \\ \text { People } & 4 \\ \text { Rate } & 8 \mathrm{mr} / \mathrm{hr} \text { (average) } \\ \text { Dose } & 256 \mathrm{pmr}\end{array}$

$\mathrm{HA}-46$

Remove HF off-gas treatment equipment.

$\begin{array}{ll}\text { Time } & 16 \mathrm{hr} . \\ \text { People } & 4 \\ \text { Rate } & <0.5 \mathrm{mr} / \mathrm{hr} \text { (average) } \\ \text { Dose } & 32 \mathrm{pmr}\end{array}$

Dose from Installation of liquid pretreatment process equipment and transfer lines.

HC $-7 \mathrm{C}$

Install ion exchange column.

$$
\begin{array}{ll}
\text { Time } & 8 \mathrm{hr} . \\
\text { People } & 4 \\
\text { Rate } & 8 \mathrm{mr} / \mathrm{hr} \text { (average) } \\
\text { Dose } & 256 \mathrm{pmr}
\end{array}
$$

Perform connections to tanks.

$$
\begin{array}{ll}
\text { Time } & 24 \mathrm{hr} . \\
\text { People } & 3 \\
\text { Rate } & 8 \mathrm{mr} / \mathrm{hr} \text { (average) } \\
\text { Dose } & 576 \mathrm{pmr}
\end{array}
$$

HA-46

Install ion exchange column.

$\begin{array}{ll}\text { Time } & 8 \mathrm{hr} . \\ \text { People } & 4 \\ \text { Rate } & <0.5 \mathrm{mr} / \mathrm{hr} \text { (average) } \\ \text { Dose } & 16 \mathrm{pmr}\end{array}$


Perform connections to tanks in the mini-canyon (average $<0.5 \mathrm{mr} / \mathrm{hr}$ )

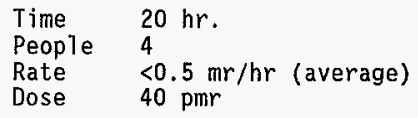

New Glovebox in Room 232 - dose for demolition and instailation if performed in Room 232 and dose for connection to off-gas and other utilities.

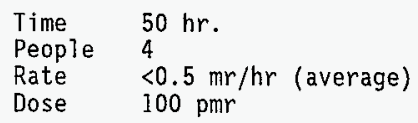

New G] ovebox in Room 228B - dose for demolition and installation if performed in Room 228B and dose for connection to off-gas and other utilities.

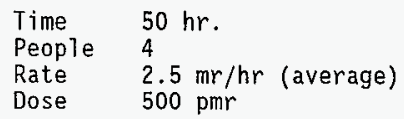

Total Dose for using a glovebox in the following locations (does not include actual dose from new Pu introduced into the IX system and load in at $\mathrm{HC}-227 \mathrm{~S}$ as this dose will be the same for all locations).

$\begin{array}{lr}\text { HC-7C } & 4812 \mathrm{mr} \\ \text { HA-46 } & 314 \mathrm{mr} \\ \text { New Gl ovebox Room 228B } & 1632 \mathrm{mr} \\ \text { New Gl ovebox Room 232 } & 326 \mathrm{mr}\end{array}$




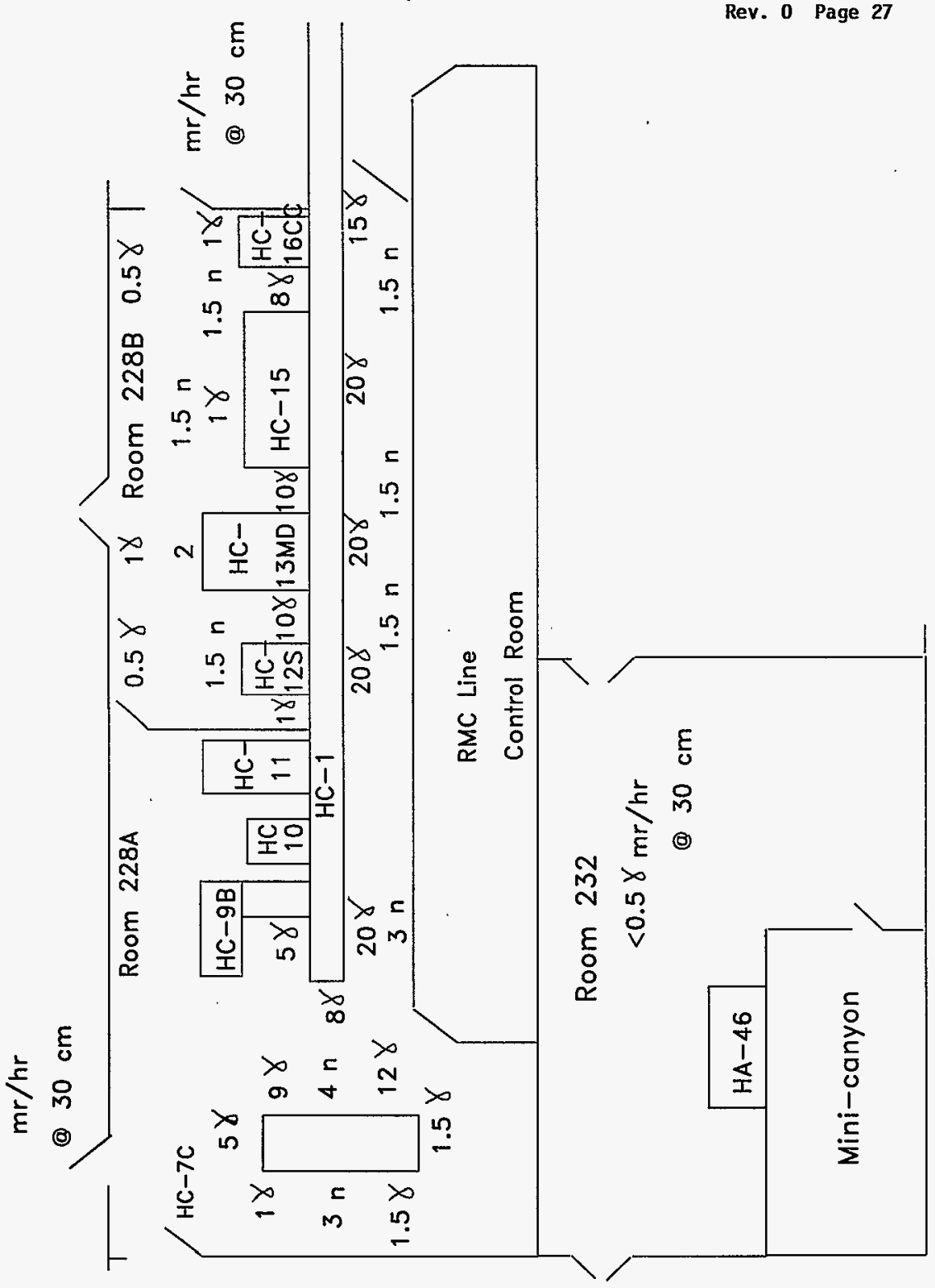




\begin{tabular}{|c|c|c|c|c|c|}
\hline \multicolumn{6}{|c|}{ DISTRIBUTION SHEET } \\
\hline \multirow{2}{*}{$\begin{array}{l}\text { To } \\
\text { Distribution }\end{array}$} & \multirow{2}{*}{\multicolumn{3}{|c|}{$\begin{array}{l}\text { From } \\
\text { PFP Process Engineering }\end{array}$}} & \multicolumn{2}{|c|}{ Page 1 of 1} \\
\hline & & & & \multicolumn{2}{|c|}{ Date May 15, 1996} \\
\hline \multirow{2}{*}{\multicolumn{3}{|c|}{$\begin{array}{l}\text { Project Title/Work Order } \\
\text { LOCATION ASSESSMENT FOR THE LIQUID PRETREATMENT PROCESS }\end{array}$}} & & \multicolumn{2}{|c|}{ EDT No. 609910} \\
\hline & & & & \multicolumn{2}{|c|}{ ECN No. N/A } \\
\hline Name & MSIN & $\begin{array}{l}\text { Text } \\
\text { With All } \\
\text { Attach. }\end{array}$ & Text Only & $\begin{array}{l}\text { Attach./ } \\
\text { Appendix } \\
\text { Only }\end{array}$ & $\begin{array}{l}\text { EDT/ECN } \\
\text { Only }\end{array}$ \\
\hline $\begin{array}{l}\text { E. C. Vogt } \\
\text { G. B. Chronister } \\
\text { W. F. Russel1 } \\
\text { R. D. Redekopp } \\
\text { C. M. Kronva1\} } \\
\text { L. H. Rodgers } \\
\text { K. R. Herzog } \\
\text { T. E. Huber } \\
\text { D. B. Koreis } \\
\text { D. P. Hughes } \\
\text { S. B. Merrick } \\
\text { M. W. Gibson } \\
\text { J. F. Durni ] } \\
\text { D. W. Macisaac } \\
\text { S. E. Nunn } \\
\text { C. D. Meng } \\
\text { Central Files }\end{array}$ & $\begin{array}{l}\text { T5-50 } \\
\text { T5-02 } \\
T 5-51 \\
\text { T5-15 } \\
\text { T5-15 } \\
\text { T5-54 } \\
T 5-50 \\
\text { T5-50 } \\
\text { T5-50 } \\
\text { R3-35 } \\
\text { T4-20 } \\
\text { T5-55 } \\
\text { T5-55 } \\
\text { S3-09 } \\
\text { T5-11 } \\
\text { T4-20 } \\
\text { A3-88 }\end{array}$ & $\begin{array}{l}x \\
x \\
x \\
x \\
x \\
x \\
x \\
x \\
x \\
x \\
x \\
x \\
x \\
x \\
x \\
x \\
x\end{array}$ & & & - \\
\hline
\end{tabular}

